The Corporate Society 
Edited by Robin Marris and Adrian Wood THE CORPORATE ECONOMY: GROWTH, COMPETITION, AND INNOVATIVE POWER 


\section{The Corporate Society}

edited by

\section{ROBIN MARRIS}

Reader in Economics, University of Cambridge, and

Fellow of King's College

Macmillan Education 
ISBN 978-1-349-01979-3 ISBN 978-1-349-01977-9 (eBook) DOI 10.1007/978-1-349-01977-9

(C) The President and Fellows of Harvard College 1974 Softcover reprint of the hardcover 1st edition 1974 978-0-333-15047-4

All right reserved. No part of this publication may be reproduced or transmitted, in any form or by any means, without permission.

First published 1974 by THE MACMILLAN PRESS LTD London and Basingstoke Associated companies in New York Dublin Melbourne Johannesburg and Madras

SBN 333150473

Library of Congress Catalog Card No. 73-14655 


\section{Contents}

Preface and Introduction

vii

SECTION I THE SOCIETY

1 Emmanuel mesthene On the ideal-real gap 1

2 THOMAS SCHELLING On the ecology of micromotives 19

3 IRENE TAVISS On contemporary social change

65

4 ROBIN MARRIS

First commentary

SECTION II THE CORPORATIONS

5 TOM BURNS

6 JOSEPH BOWER

7 KENNETH ARROW

8 ROBIN MARRIS
On the rationale of the corporate system

On the amoral organization

On the agenda of organizations

Second commentary

\section{SECTION III THE PUBLIC SECTOR}

9 RICHARD MUSGRAVE On social goods and social bads

10 MANCUR OLSON

On the priority of public problems

11 E. J. MISHAN

On the economics of disamenity

Third commentary

Conclusion

85

7




\title{
Preface and Introduction
}

\begin{abstract}
'Everyone hates airports : they are the most loathsome of neighbours, assaulting the decencies of human life for many miles around. Yet everyone, or almost everyone, wishes to travel by air, either to make money or to spend it' (J. W. M. Thompson, London Sunday Telegraph, February 11, 1973).
\end{abstract}

This book is the result of a project sponsored by the Harvard University Program on Technology and Society, and is, in fact, the second (and final) volume to emerge from that particular project. The first was entitled The Corporate Economy, ${ }^{1}$ published in May 1971. The project was generally concerned with the idea that 'something had gone wrong' with modern industrial society: our object was to try to bring to bear the analytical tools of social science in an endeavour to identify more precisely the possible causes and cures.

Of course we were over-ambitious. The first volume was intended to represent a strictly economic analysis of the way an economic system of large scale oligopoly actually works - in preparation, as it were, for a more general and more normative study in the second volume. Professor Edith Penrose, in a kind review of the first volume, plainly hinted that she thought the second volume would probably prove we had been aiming too high. She was quite right. Our intention has been to draw on the work of professional sociologists, economists ${ }^{2}$ and organization theorists and weld their contributions into some kind of grand synthesis. In the event, we have obtained a series of papers which I believe readers will find original, helpful and stimulating; I have written some commentaries and suggested conclusions but I cannot pretend to have even begun to achieve a synthesis.

We did not, in fact, continue to concentrate exclusively on the

1. The Corporate Economy, R. Marris and A. Wood (eds), with chapters by Kenneth Arrow, G. C. Archibald, William Baumol, John Eatwell, E. Filippi, G. Zanetti, John Lintner, Siro Lombardini, Robin Marris, Robert Solow, Oliver Williamson, Adrian Wood (Macmillan, London, and Harvard University Press, 1971).

2. In the event the proportion of economists among the contributors was higher than I would have wished. But I think it can be argued that the economists who were recruited are notably polymorphous. 
corporate sector (and we have not pursued, as we should have done, the problem of the effects of advertising, as Professor Penrose also suggested) because we found ourselves increasingly drawn into the arena of public goods and social choice. There are in fact three essays on corporations, three on public goods and 'externalities' and three on social organization - the last printed first, the first second and the second last. As in the case of the first volume, the original drafts of the papers were discussed at a conference attended by the authors and some other participants, but we have not, as we did in the first case, seen our way to providing a separate chapter discussing the conference as such.

All this conceded, I claim a definite logic for the structure of the work as it has finally emerged. Our society can be seen as three ensembles: the ensemble of political and administrative institutions we call 'government' or 'public sector'; the ensemble of corporations and un-incorporated commercial enterprises we call the private business sector and finally the ensemble of social groups and individuals, into which the population has arranged its domestic life and which, for want of a better word, we call 'the community'. There are also intermediate institutions, such as charitable foundations and other not-for-profit bodies lying between the public and private sectors. The functions of each ensemble can be described on several, but parallel, dimensions: thus the public sector is at the same time the expression of the political process developed by the community for the conduct of national affairs, and the provider of what economists call 'public goods' with which this volume is particularly concerned. The corporations are both the production units for 'private goods' and the social and organizational environment in which the great proportion of the paid members of the community spend their working day and experience the pleasures and pains of the social aspects of their working lives. The households and families of which the community is composed are to the economist the 'basic consumer unit'; to the sociologist, the basic institution of domesticity. This multi-dimensional and interrelated picture of our society lies at the back of the approach we have adopted. The approach can be illustrated by mentioning some of the typical contemporary criticisms. It is said, for example, that the organizations (whether government 
or 'private') in which most people work have become too large and impersonal, while at the same time a number of more specific economic criticisms are levelled at the activity of the corporate sector as such - the economic power of large corporations is said to be increasing too rapidly, competition to be declining, and the sovereignty of the consumer made meaningless by advertising and other forms of sales promotion. It is said that the whole society has become excessively 'consumeristic', increasingly dominated by simulated wants for ever less useful mechanical gadgets, and that this result is the product both of the behaviour of the corporations and the collusion of the government. It is said that the entire economic and social orientation of the society is governed by the needs of an amorphous élite (J. K. Galbraith's 'Technostructure') consisting of the entire white-collar staff of corporations and government (both sectors being seen as increasingly merging in function). It is said that government has become both too active and too remote, while at the same time it is said that the system as a whole is biased to produce too few public goods, or to produce the wrong kind of public goods, or to produce public goods inefficiently. (Of course, other critics believe too many resources are devoted to the public sector, but all agree that there is something wrong.) It is said, and by some with great passion, that the distribution of affluence is grossly inequitable and that the persistence of substantial poverty is a scandal. Finally, it is said, and with increasing force and frequency, that the whole of society is gravely mismanaging the handling of what the economist calls 'externalities' and what the layman is coming to refer to loosely as the 'environment'. A full list could be very much longer (for example, to the rebellion of some youth against the institution of the family can be added their rebellion against bureaucracy); the foregoing concentrates on points of particular relevance for the present volume. These essays, although individually concerned with specific areas or problems, in being brought together are intended to illuminate the interconnections between the diagnoses, as well as between possible remedies, of the various suggested maladies. Thus as well as presenting social and economic problems in their own traditional sphere, the corporations are of interest in connection with 'public' goods because it is a combination of characteristics both of public goods and of the profit-seeking businesses that insists, on the one hand, that public goods cannot be marketed c.s. $-1 *$ 
by corporations (although in some circumstances they may 'produce' them) while, on the other, the government may not provide them very well. In other words, it is the system of 'mixed economy' and 'mixed society' as a whole that creates the various individual problems, even though each problem at first appears to reside mainly in one sector or another. The New Left sees the whole as a diabolical conspiracy. Our approach, though radical as it turns out, is hopefully more objective.

\section{The format}

Originally, this editor wrote a paper, representing a response to the other papers, for discussion at the conference. It was intended to be the embryo synthesis, but although it attracted much helpful comment, I eventually decided the egg would never hatch. Instead it was decided to break up the material from the paper into three 'Commentaries' to be placed, as they have been, at the end of each of the three groups of papers. These commentaries are in no sense intended to be expository: they are the results of reading the papers and my own thinking. In other words, they represent my own contribution to the project and should stand or fall as such. I found, however, that some of the original material was unsuitable for the commentary format, and it is included, as already indicated, in the attempted Conclusion.

The first group of papers begins with an essay by Emmanuel Mesthene which is partly his own contribution to the general project and partly a more specific introduction to the present volume (but more of Mesthene's role later): he is concerned with the way inadequate information contributes to the idealreal' gap between what society wants to do and what is actually happening. The second paper is a spirited description and analysis by Thomas Schelling of ways our present society and especially the North American example, succeeds and fails in handling a wide range of problems where individual choice conflicts with social values. The third paper by Irene Taviss is a scholarly and comprehensive acount of the way the sociologist sees these kinds of problems with her own interpretation of the implications.

In the second group, 'The Corporations', none of the essays 
is concerned with strictly economic aspects of the subject, although one contributor, Kenneth Arrow, is a Nobel Laureate for economics (and his present contribution, a speculative application of information theory, is characteristically original). The group begins with a wide-ranging (and in my view deepthinking) study of the sociology of the corporate system by Tom Burns, who holds the Chair of Sociology at Edinburgh, and continues with a study by Joseph Bower, who is a Professor in the Harvard Business School: his piece 'On the Amoral Corporation' is essentially concerned with the way in which the combination of modern 'efficient' management with 'limited liability' (in the more general sense of the expression) has created in the large corporation an institution which with the best will in the world cannot accept social responsibility. Kenneth Arrow's piece is designed to show how the informational needs of the large organization leads to the evolution of a modus operandi such that institutional conservatism becomes inevitable.

The third group. 'The Public Sector' opens with a classic survey of a field which the author, Richard Musgrave, has himself done much to create, namely the 'theory' of social goods and bads, and also includes a factual survey of developments in the public sector, including trends in the share of national income accounted for by government civilian expenditure. There follows a particularly important contribution by Mancur Olson, in which he develops the (to me) original idea that the basic difficulty with public goods (and hence a major cause of contemporary dilemmas) is that, because their output cannot be effectively measured, we never know whether we are producing them 'efficiently'. Finally, the contributions close with an essay by Mishan - a characteristically sharp exposition of and exhortation on the handling of 'pollution' problems. My own conclusion, which follows the third commentary, is sub-titled 'the institutional needs of a better society'.

\section{Acknowledgements}

I badly missed Adrian Wood, who became embroiled in another piece of research. I had a lot of help from my secretary, Anne Shrewsbury, and from Jane Draper of the HUPTS staff. But the 
main weight of acknowledgement must be placed on the head of Emmanuel Mesthene. He conceived the whole project. In the case of the first volume, most of the execution was undertaken by myself and Adrian Wood. But in the case of the present volume, things were very different. Although I have done most of the actual work of editing, 'Manny' had the leading influence on the nature and content of the book. It was he who saw the significance of attempting to integrate the study of corporations with the study of the problems of public goods and social choice; and it was Manny who recruited virtually all the contributors. In drawing out these essays from my colleagues, he has in my view made a substantial contribution to knowledge.

The date which follows, much too long after the conference and the completion of the papers, deserves explanation and apology, both to the public and to my colleagues. I spent far too long in attempting the 'synthesis that failed' and the commentaries themselves seemed to need revision after revision.

February 1973

R. L. M. 